\title{
ПЕТРОГЛИФЫ КАНОЗЕРА 2020: НОВЫЕ ФИГУРЫ И ТИПОЛОГИЯ
}

\author{
(C) 2020 Е.М. Колпаков
}

Институт истории материальной культуры РАН, г. Санкт-Петербург

Статья поступила в редакцию 23.09.2020

\begin{abstract}
Представлены наиболее интересные открытия наскальных изображений последних лет в комплексе петроглифов Канозера на Кольском полуострове. Показаны их типологические связи с комплексами Чальмн-Варрэ и Залавруги.

Ключевые слова: петроглифы, Северная Фенноскандия, Канозеро, типология.
\end{abstract}

DOI: $10.37313 / 2658-4816-2020-2-4-135-142$

\author{
Работа выполнена в рамках программы ФНИ ГАН \\ по теме государственного задания № 0184-2019-0011 \\ «Первые люди на Севере России: \\ Арктика и Субарктика в позднем плейстоцене и раннем голоцене».
}

\section{Введение}

Петроглифы Канозера на Кольском полуострове (рис. 1) - один из крупнейших комплексов наскальных изображений Фенноскандии неолита и бронзового века, первые выбивки на котором были открыты всего лишь в 1997 г. ${ }^{1}$, а полная публикация осуществлена в 2012 г. $^{2}$

Исследования петроглифов Канозера не прекращаются, и в 2017-2019 гг. ряд неопознанных и незафиксированных ранее фигур был обнаружен сотрудником музея «Петроглифы Канозера» Вадимом Лихачевым на острове Еловый ${ }^{3}$ В 2019-2020 гг. Кольской археологической экспедицией ИИМК РАН были обнаружены и предварительно документированы новые выбивки на озере Канозеро ${ }^{4}$. Всего документировано около сотни новых фигур на острове Еловый (рис. 2).

Необходимо отметить, что скалы Канозеpa, на которых выбиты петроглифы, сложены из сланцев (серицит-амфибол-хлоритовых и/или серицит-хлорит-амфиболовых). Они

Колпаков Евгений Михайлович, доктор исторических наук, ведущий научный сотрудник Отдела палеолита. ORCID 0000-0002-5648-3406.

E-mail:eugenkolp@yandex.ru достаточно мягкие и легко повреждаются. Искусственные выбивки на них сохранились в разной степени: от хорошо опознаваемых до практически неразличимых. Сами скальные поверхности несут многочисленные повреждения. Поэтому выявление выбитых фигур и их фиксация во многих случаях требуют длительного исследования и не сводятся к простой формуле «пришел, увидел, начертил». Часть новых фигур относится к категории плохо различимых.

\section{Новые фигуры}

В группе Еловый 1 зафиксировано 4 чашевидных углубления, образующих звериный след, аналогичный открытому ранее.

В группе Еловый 3 зафиксировано 72 фигуры (по номерам на чертеже): антропоморфы - 18, зооморфы - 15, орнаменты - 3, геометризованная голова медведя - 1 , лодки - 2, кинжал - 1 , лапа -1 , крест - 1 , лыжня - 2, линии - 11 , неясные фигуры - 10 , отдельные чашевидные углубления и мелкие круги - 7. В нашей публикации памятника приводится 66 фигур в этой группе ${ }^{5}$. Таким образом количество фигур увеличилось более чем в два раза. 


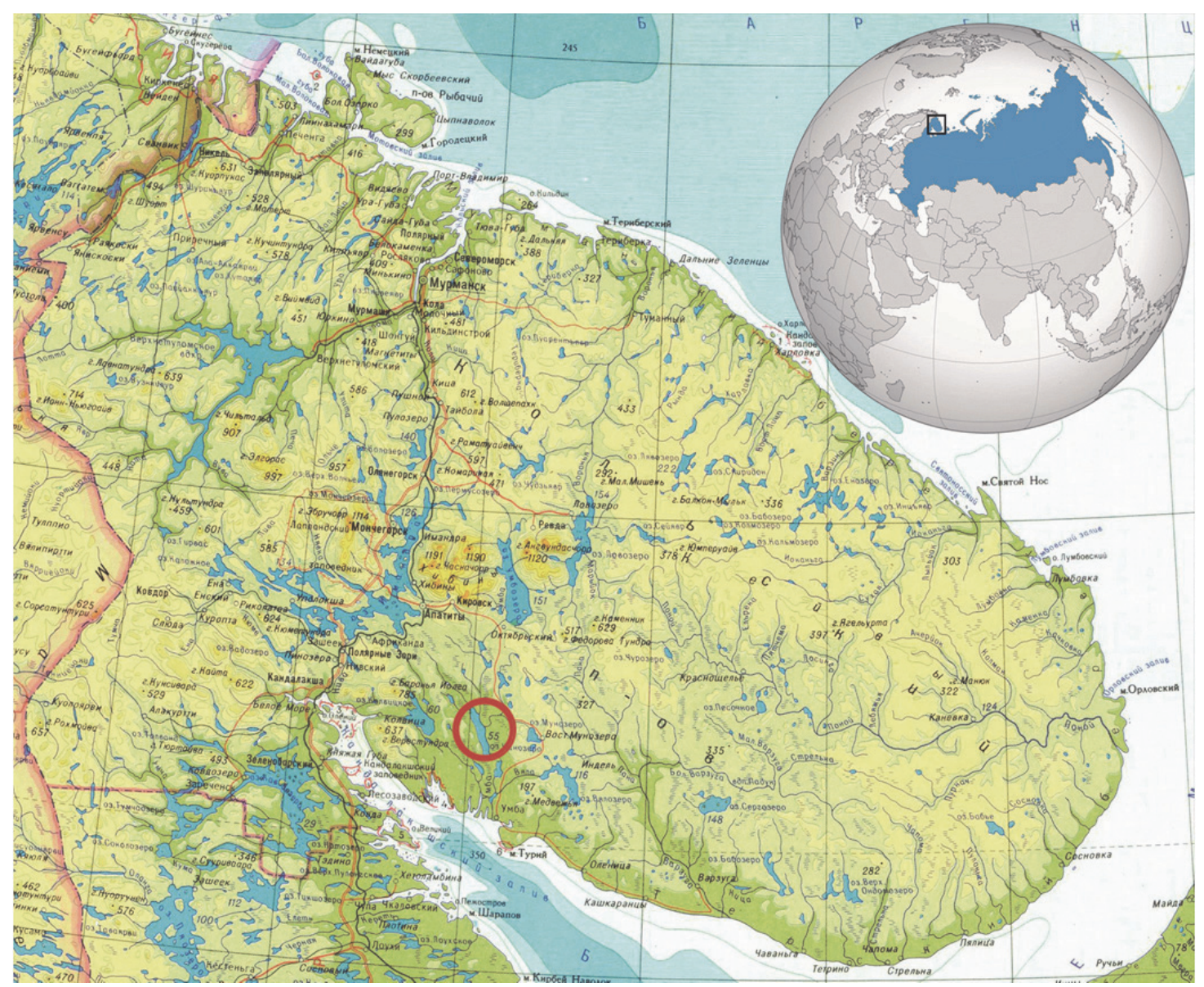

Рис. 1. Канозеро на карте

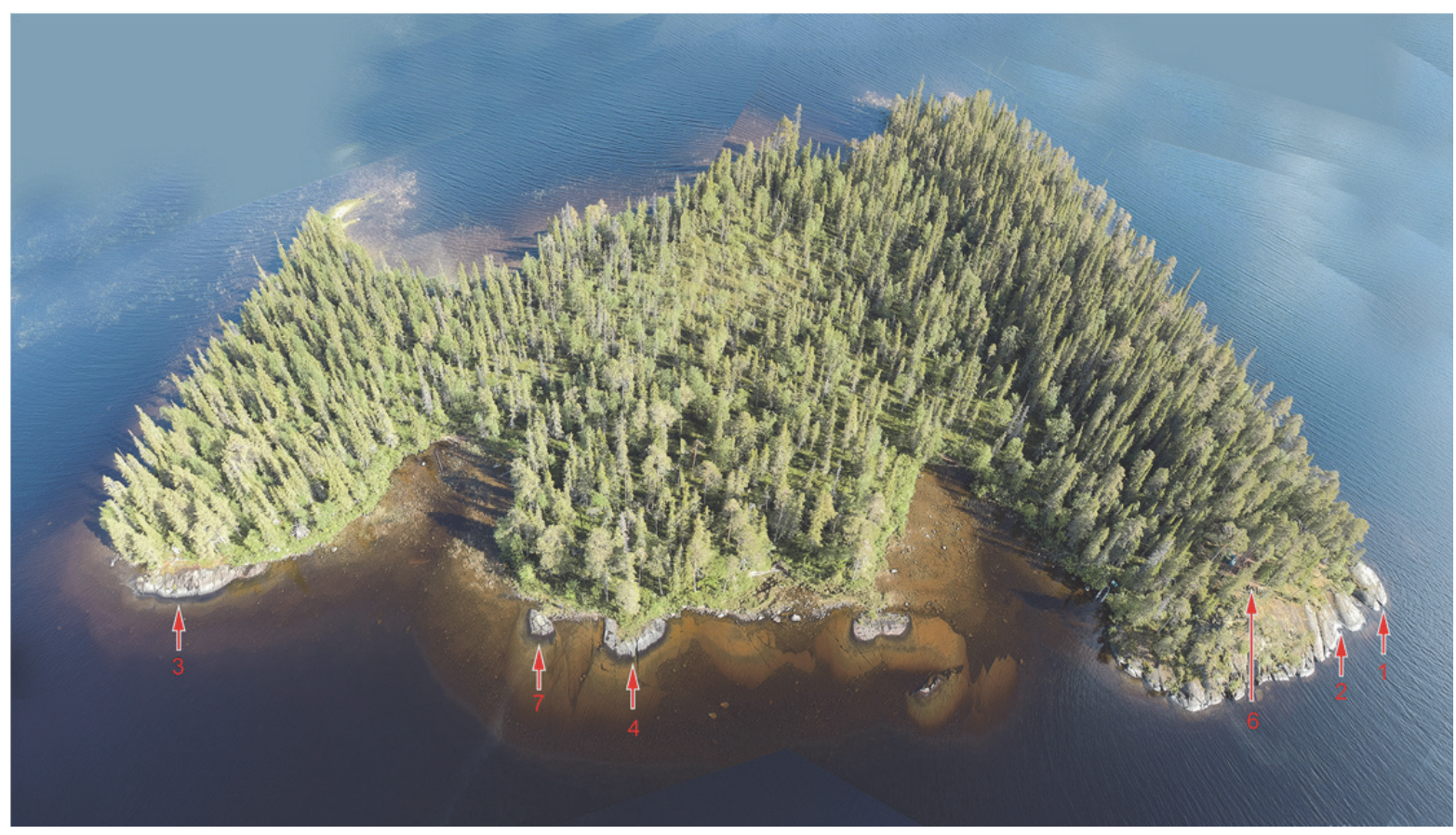

Рис. 2. Канозеро. Остров Еловый и расположение групп петроглифов. Вид с С3

В группе Еловый 6 зафиксировано 15 фигур (ранее была 216): антропоморфы - 2, зооморфы - 1, линии - 2, неясные фигуры 8, мелкие круги - 2 .
В новой группе Еловый 7, на отдельном уходящем в воды озера маленьком скальном мысу, зафиксировано 2 лодки и 2 фигуры китообразных ${ }^{7}$. 


\section{Типологический анализ}

Особый интерес представляют типологические связи недавно открытых фигур. С одной стороны, новые фигуры укладываются в типологию Канозерских петроглифов, представленную в наших публикациях ${ }^{8}$, с другой стороны, позволяют сделать существенные новые выводы или усилить имеющиеся предположения.

1. В группе Еловый 6 разбор скопления неясных выбивок привел к выявлению фигуры зооморфа с «калачевидными» ногами (рис. 3,4$)$. Такой прием в изображении зооморфов имеется только в петроглифах Чальмн-Варрэ на Поное ${ }^{9}$ и до сих пор не встречался на других памятниках наскального искусства (рис. 5). Прием весьма специфичный для того, чтобы допускать его независимое изобретение в разных коллективах.

Совсем недавно мы писали, что «наибольшее сходство петроглифы ЧальмнВаррэ имеют с петроглифами Канозера, ближайшими к ним географически», но при этом «однозначная интерпретация отдельных сходств петроглифов Чальмн-Варрэ с

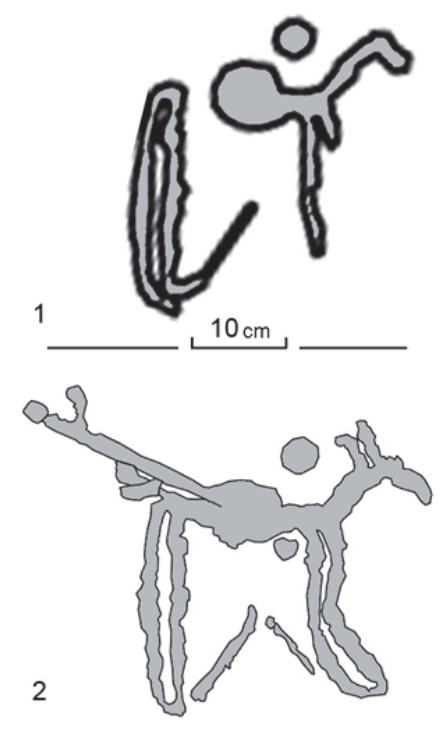

Рис. 3. Канозеро. Группа Еловый 6. Зооморф с «калачевидными» ногами. 1 - чертеж 2005 г., 2 - чертеж 2020 г.

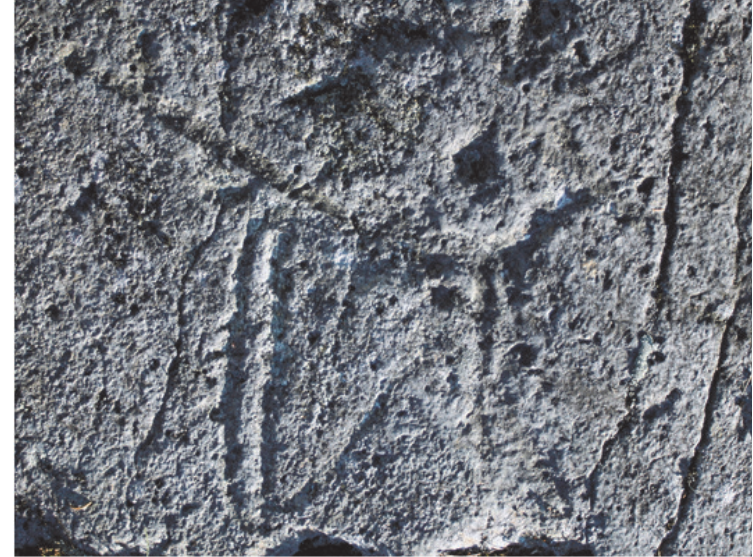

Рис. 4. Канозеро. Группа Еловый 6. Зооморф с «калачевидными» ногами. Вид с С.

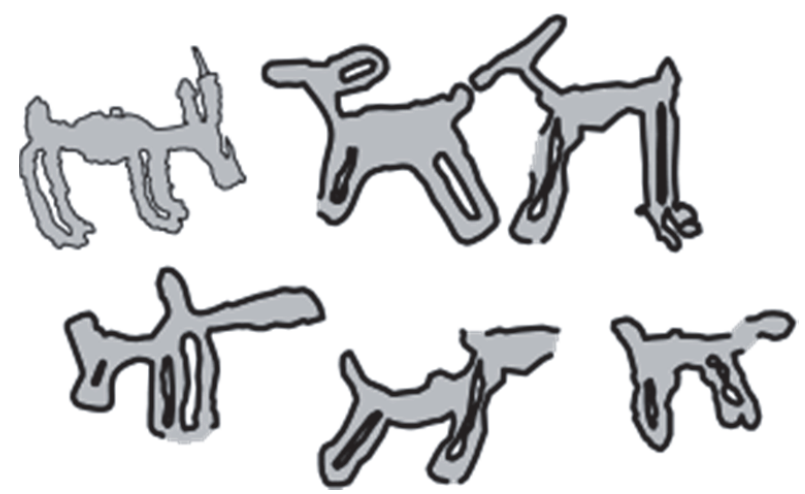

Рис. 5. Чальмн-Варрэ. Зооморфы с «калачевидными» ногами (по: Колпаков и др., 2018: 102-103)

Канозером пока вряд ли возможна. Сходство между ними в показанных элементах могло возникнуть как благодаря контактам их создателей, так и независимо друг от друга. Прямые контакты здесь сомнительны, поскольку нет сходства между целыми фигурами и есть всего одна сходная композиция» ${ }^{10}$. Теперь, напротив, на вопрос о существовании прямых связей между создателями петроглифов Канозера и ЧальмнВаррэ можно ответить утвердительно.

Где возник прием «калачевидных» конечностей? В петроглифах Чальмн-Варрэ «наблюдается своеобразный типологический ряд по этому признаку: нормально разделенные конечности - ноги касаются друг друга своими нижними концами - концы ног сливаются вместе - пара ног образует овал» ${ }^{11}$. На Канозере есть только начало и конец этого типологического ряда. Таким 
образом, имеющиеся факты свидетельствуют в пользу формирования приема «калачевидных» конечностей в Чальмн-Варрэ.

2. Остальные наиболее интересные открытия сделаны в группе Еловый 3. Прежде всего, это антропоморф анфас пораженный стрелой в руку или грудь (рис. 6, 7). Три аналогичных персонажа известны только на Старой Залавруге в Карелии (рис. 8), где они изображены в профиль ${ }^{12}$. На Канозере изображения стрел и пораженных ими антропоморфов до сих пор не обнаруживались. Впрочем, необходимо отметить, что через эту фигуру проходит тре-

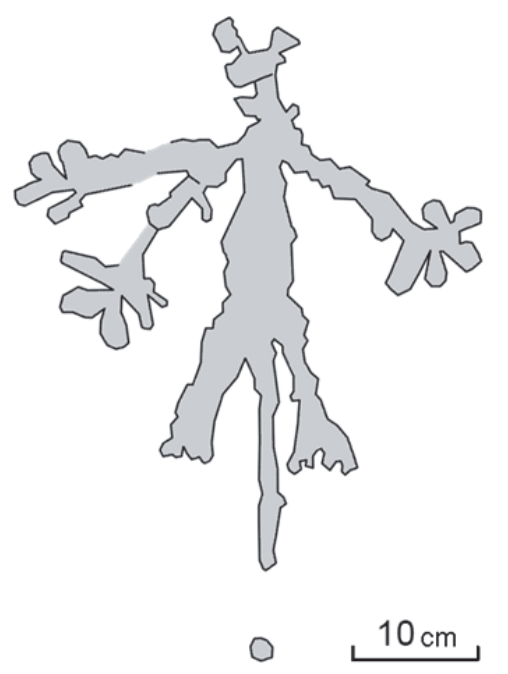

Рис. 6. Канозеро. Группа Еловый 3. Пораженный стрелой антропоморф

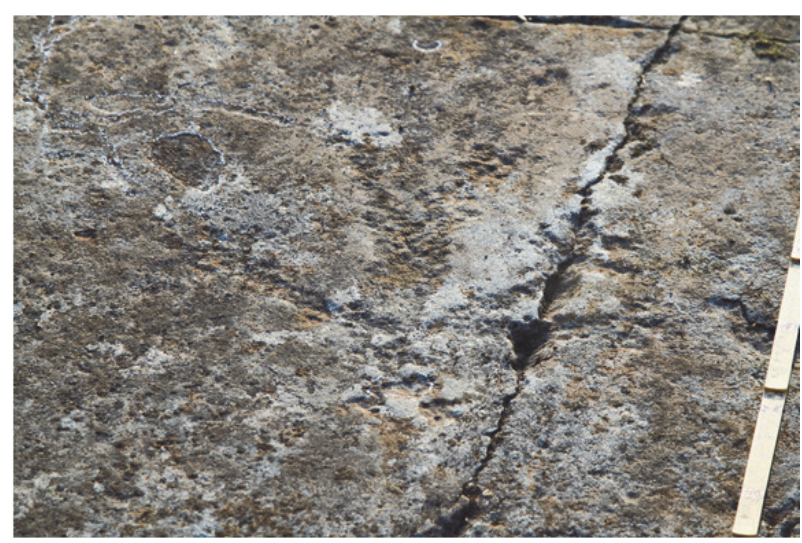

Рис. 7. Канозеро. Группа Еловый 3. Пораженный стрелой антропоморф. Вид с ЮВ

щина в скале и выбивка сохранилась плохо. Работа по анализу изображения должна быть продолжена. Некоторое сходство по ряду признаков петроглифов Канозера и Залавруги отмечалось и ранее ${ }^{13}$.

3. Открыты две очень сходные композиции лыжной охоты на лося или преследования зверя (рис. 9, 10). Хотя они весьма далеки от известной сцены охоты Залавруги 4 и намного проще нее, все же в них использованы такие же приемы изображения лыжни сплошными линиями и следов от лыжных палок кружками. Они расположены близко друг к другу и, возможно, составляют единую композицию.

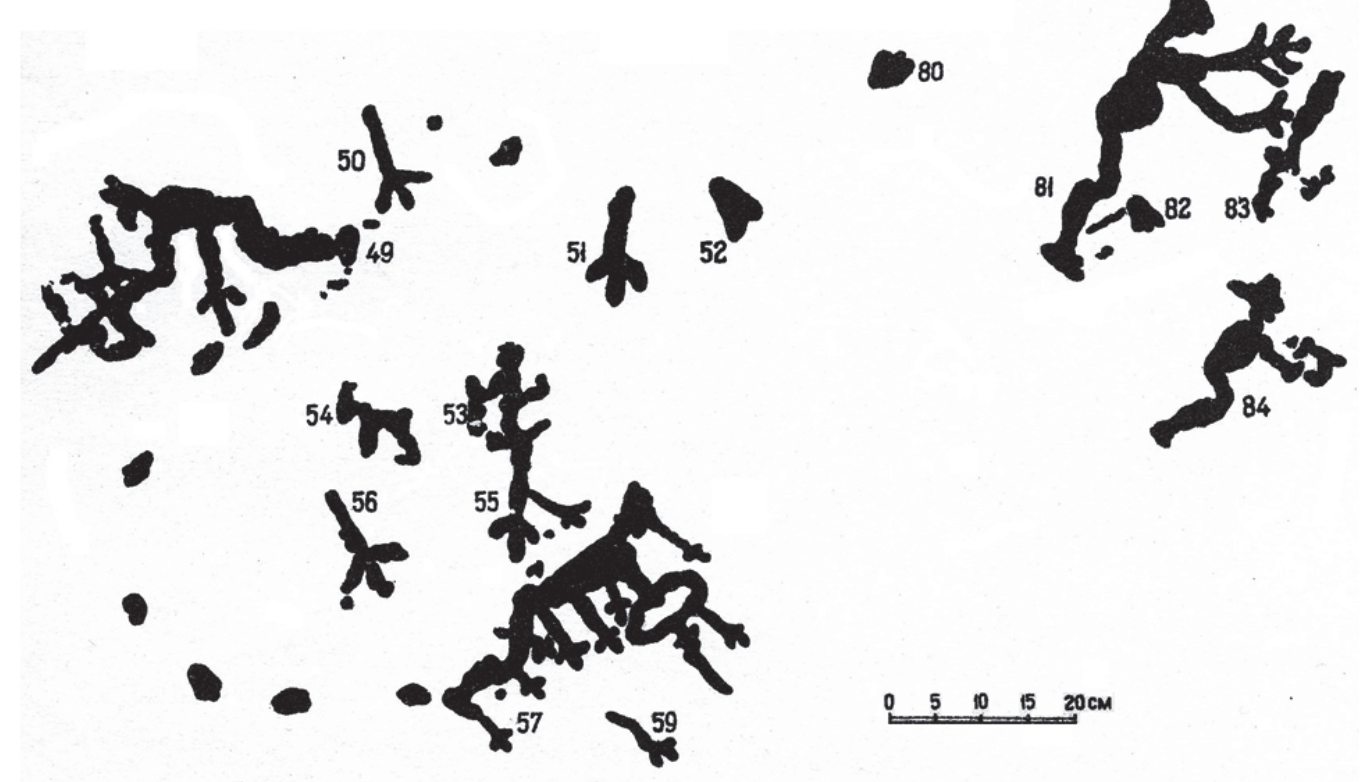

Рис. 8. Старая Залавруга.

Пораженные стрелами антропоморфы (по: Равдоникас 1938: табл. $3^{14}$ ) 
1
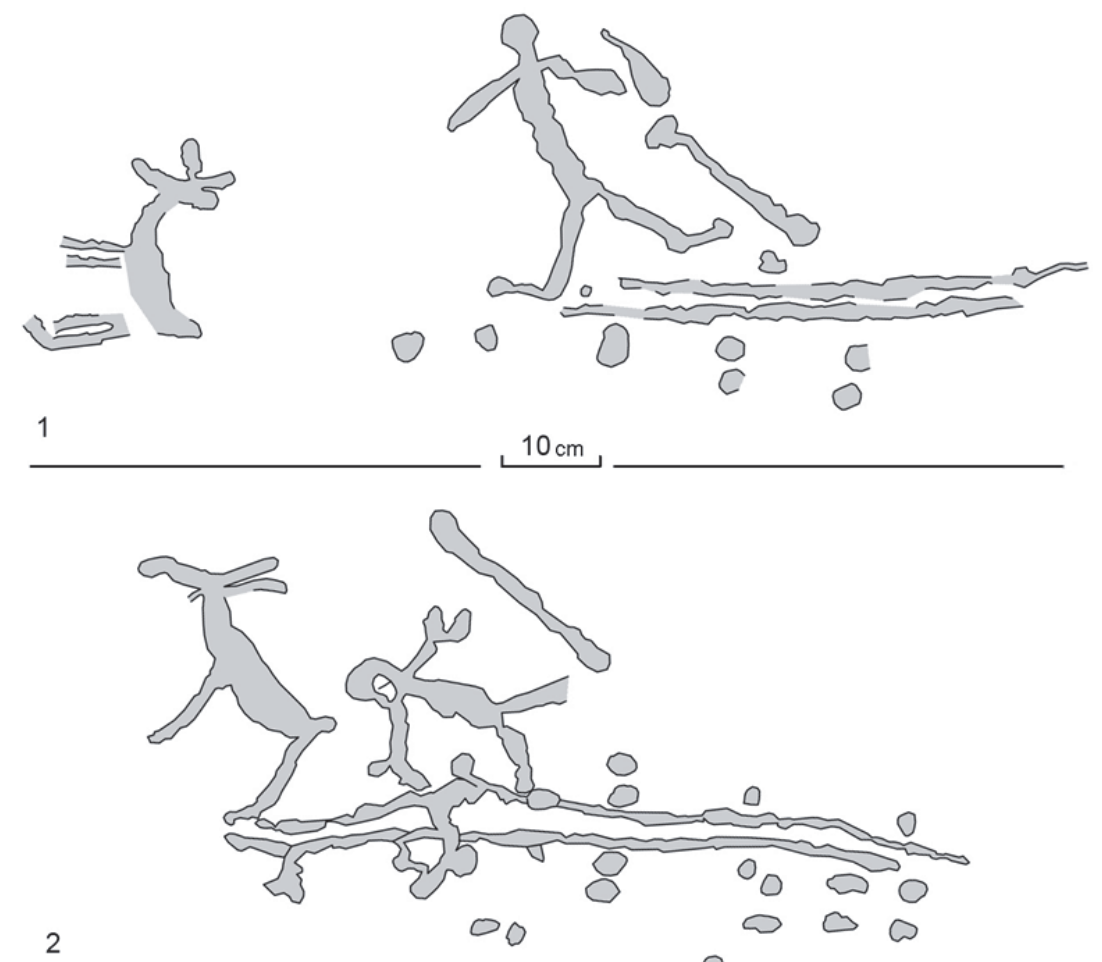

O

Рис. 9. Канозеро. Группа Еловый 3. Сцены лыжной охоты

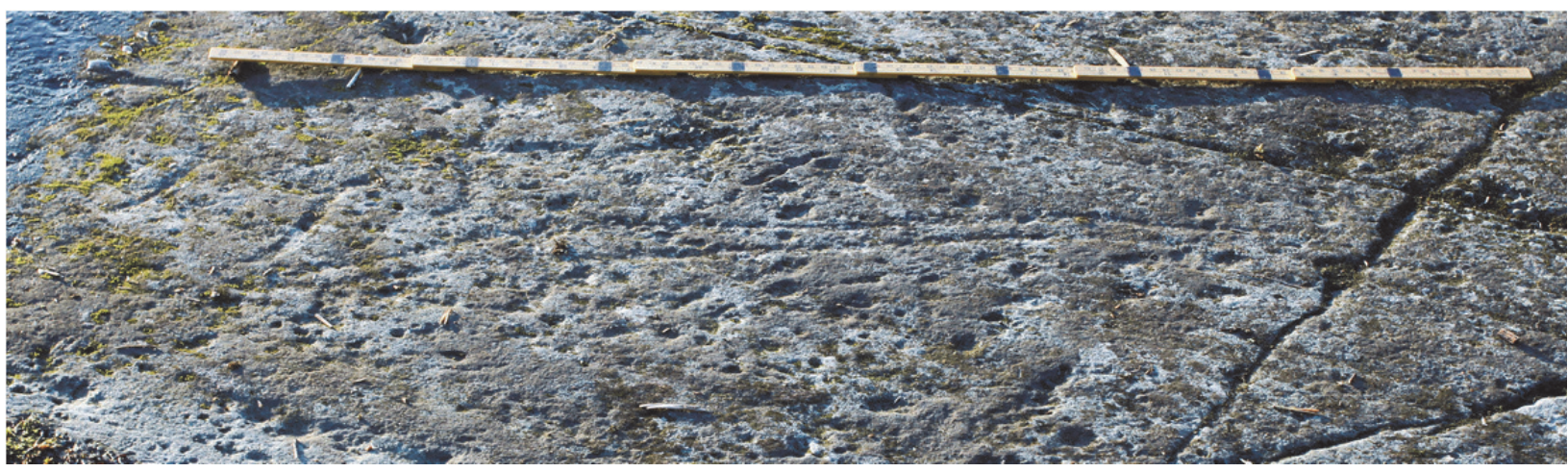

Рис. 10. Канозеро. Группа Еловый 3. Сцена лыжной охоты. Вид с Ю

4. Профильный зооморф (лось) с идущей от спины кверху вертикальной линией, заканчивающейся округлой фигурой (рис. 11, $12)$, имеет единственную близкую аналогию в онежских петроглифах на Пери-Нос 6 (рис. 13). Это многократно обсуждавшийся олень «с идущей от спины кверху вертикальной линией, заканчивающейся правильным кружком... солярным знаком» ${ }^{15}$, или олень «с хвостягой, воткнутой в спину» ${ }^{16}$.

В одной сцене на Канозере лоси поражаются в спину стержнями с кольцами на тыльном конце. Однако стержни в этом случае располагаются под острым углом к спине поражаемого зверя, также как у описан- ного выше зооморфа с «калачевидными» ногами из группы Еловый 6. По всей видимости, зооморфы с перпендикулярными и с наклонными стержнями в спине должны рассматриваться вместе. Не исключено, что в обоих случаях изображена охота.

5. Обнаружено 3 фигуры, которые можно охарактеризовать как геометрические орнаменты (рис. 14). Ранее на Канозере такие фигуры не встречались. Особенно примечателен один из них, выглядящий как ромбический меандр или частично вложенные незамкнутые ромбы (рис. 14-1). С одной стороны, он заметно отличается от геометрических орнаментальных фигур норвеж- 


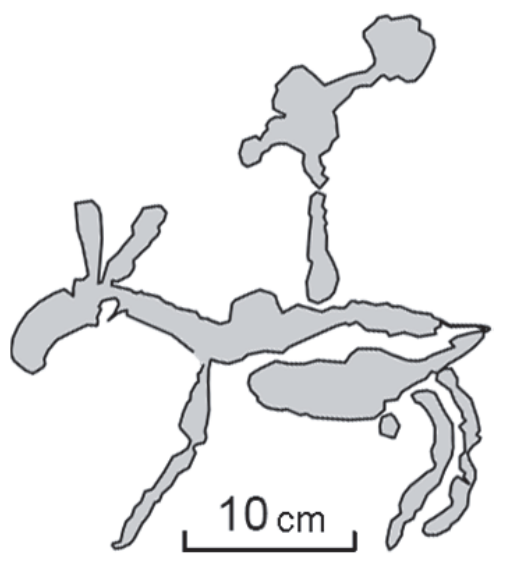

Рис. 11. Канозеро. Группа Еловый 3. Зооморф со стержнем и округлой фигурой над спиной

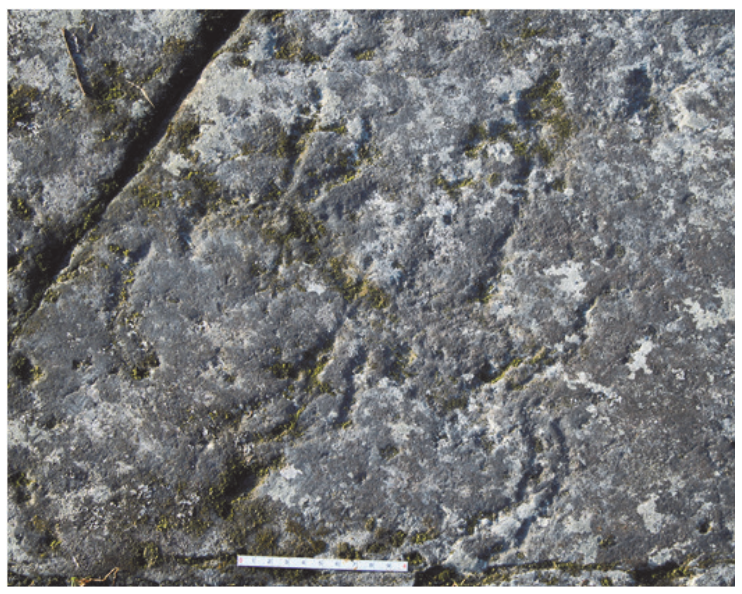

Рис. 12. Канозеро. Группа Еловый 3. Зооморф со стержнем и округлой фигурой над спиной. Вид с Ю3

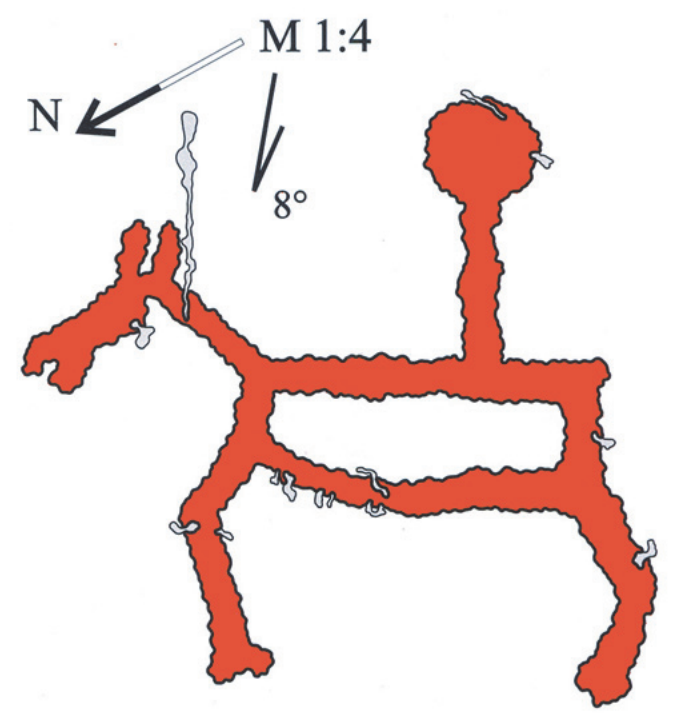

Рис. 13. Онего. Пери Нос 6. Зооморф со стержнем и округлой фигурой над спиной (Poikalainen, Ernits 2019: 553 $3^{17}$ )
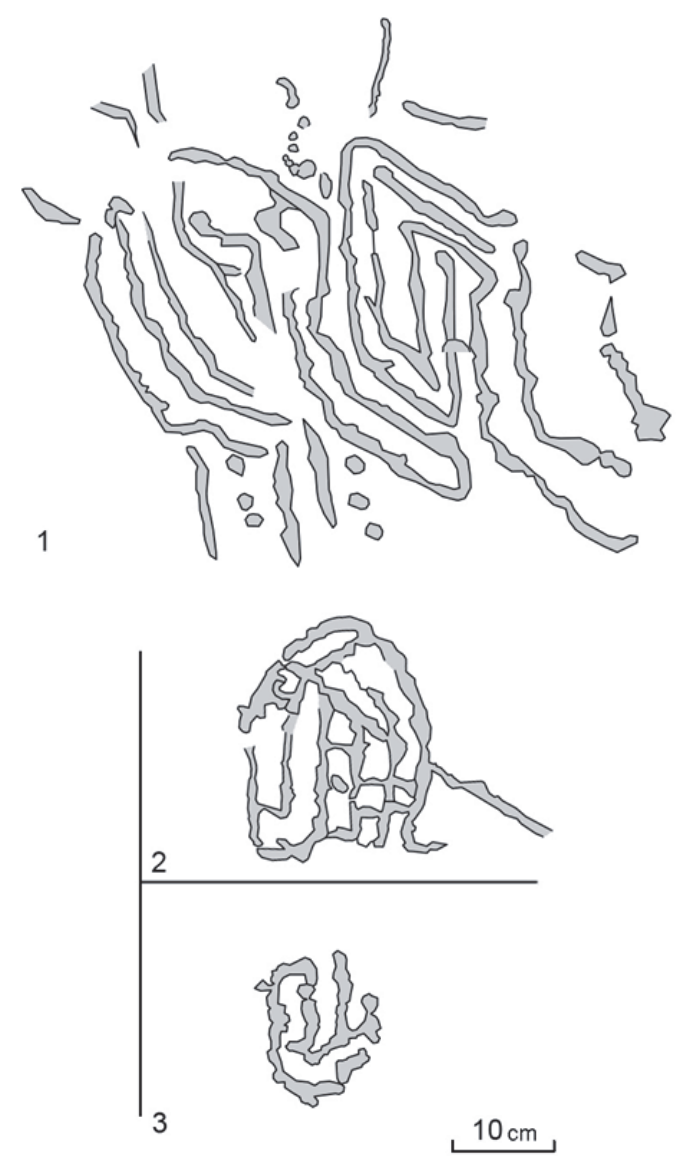

Рис. 14. Канозеро. Группа Еловый 3. Геометрические орнаменты

ской Альты. С другой стороны, он напоминает некоторые фигуры на писанице Пяйве и гравировки на костяных предметах, относящиеся к неолиту и бронзовому веку Северной Фенноскандии ${ }^{18}$.

6. Красивый результат дало новое исследование одной из фигур, которая раньше представлялась достаточно ясной. У антропоморфа е3n36 ${ }^{19}$ удалось разобрать лосиную голову (рис. 15-1, 16). Очень сходная фигура с лосиной головой (рис. 15-2) была известна на Канозере ранее ${ }^{20}$, и обе даже помещались нами в одну типологическую группу $^{21}$, как и композиции с ними ${ }^{22}$. Теперь имеется две фигуры антропоморфов с несомненной лосиной головой, которые можно связать с саамской традицией - легендой о Мяндаше - человеке-олене ${ }^{23}$.

7. Обнаружена еще одна (восьмая) фигура вписанного креста (рис. 17). Тип фигуры, имеющийся только на Канозере и в норвежской Альте ${ }^{24}$. 


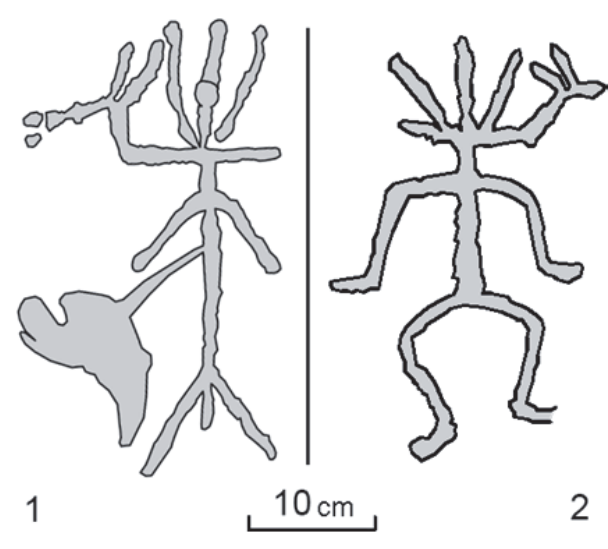

Рис. 15. Канозеро. Антропоморфы с лосиной головой:

1- группа Еловый 3, 2 - скала Одинокая

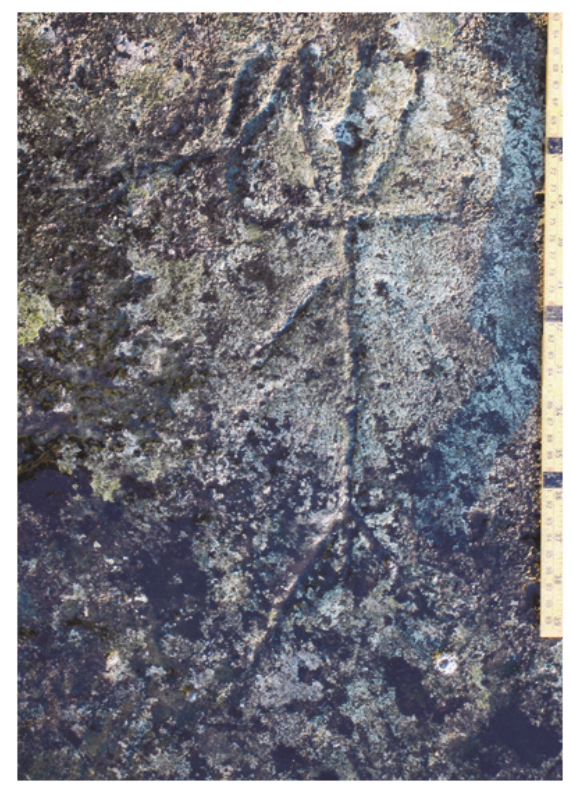

Рис. 16. Канозеро. Группа Еловый 3. Антропоморф с лосиной головой. Вид с С

8. Дополняют свои типологические ряды «трехлепестковая» геометрическая фигура и сцена «дефлорации» 25 .

9. Совершенно новой фигурой с точки зрения типологии является изображение кинжала (рис. 18), правда, очень плохой сохранности. По форме оно ближе всего к европейским кинжалам бронзового века. Надо заметить, что изображения различных орудий на Канозере, как и вообще в наскальном искусстве Северной Фенноскандии, слишком условны, чтобы связывать их с известными типами археологических артефактов (в отличие от наскального искусства юга

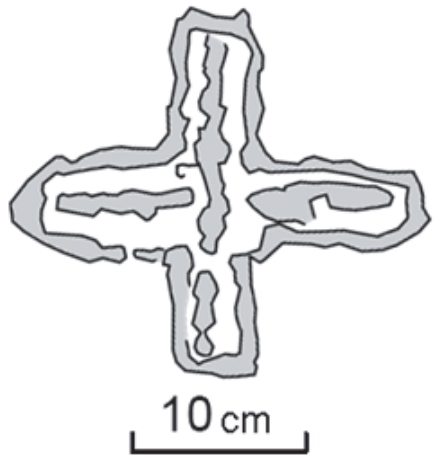

Рис. 17. Канозеро.

Группа Еловый 3. Крест

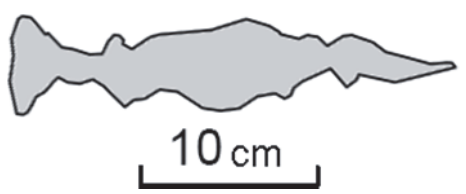

Рис. 18. Канозеро.

Группа Еловый 3. Кинжал

Европы). Открытое изображение кинжала впервые претендует на то, чтобы быть соотнесенным если и не с конкретным типом кинжалов, то хотя бы с группой типов.

\section{Заключение}

В целом новые петроглифы на Канозере хорошо укладываются в предложенную ранее типологию. Безусловно, важным является открытие существенных типологических связей с петроглифами Чальмн-Варрэ и Залавруги. Предположительное изображение бронзового кинжала, если оно подтвердится в дальнейших исследованиях, откроет новые возможности в интерпретации наскальных выбивок Канозера. Не вызывает сомнений, что в ближайшие годы нас ждут новые открытия на Канозере.

\section{ПРИМЕЧАНИЯ}

1 Лихачев В.А. Рисунки Канозера. Открытие, изучение, сохранение. Апатиты, 2011. 126 с.

${ }^{2}$ Колпаков Е.М., Шумкин В.Я. Петроглифы Канозера. Rock Carvings of Kanozero. СПб.: Искусство России. 2012. 424 с., рус., англ., ил.

3 Likhachev V. Kanozero petroglyphs: history of discovery and investigation//Adoranten. Yearbook of the Scandinavian Society for Prehistoric Art 
(Sweden): Museum of Rock Carvings. Tanum, 2018. P. 48-71.

${ }^{4}$ Колпаков Е.М., Киселева А.М. Петроглифы Канозера: открытия 2019 г. // Первобытная археология: журнал междисциплинарных исследований. № 2. 2019. С. 149-158.

${ }^{5}$ Колпаков Е.М., Шумкин В.Я. Петроглифы Канозера. Rock Carvings of Kanozero. СПб.: Искусство России, 2012. С. 28, 39-42.

${ }^{6}$ Там же.

${ }^{7}$ Колпаков Е.М., Киселева А.М. Указ. соч.

${ }^{8}$ Колпаков E.M. Петроглифы Канозера: типологический анализ (по состоянию на 2005 г.) // Кольский сборник: К 60-летию В.Я. Шумкина. СПб.: «Элексис Принт», 2007. С. 155-183; Колnаков Е.М., Шумкин В.Я. Указ соч. С. 290-331.

${ }^{9}$ Колпаков Е.М., Шумкин В.Я., Мурашкин А.И. Петроглифы Чальмн-Варрэ. Čalmn-Varrė petroglyphs. СПб.: ЛЕМА, 2018. С. 102.

${ }^{10}$ Там же. С. 113.

${ }^{11}$ Там же. С. 102.

${ }^{12}$ Равдоникас В.И. Наскальные изображения Онежского озера и Белого моря. Ч. 2: Наскальные изображения Белого моря. Les Gravures Rupestres des Bords du lac Onega et de la mer Blanche. Seconde Partie: Les Gravures Rupestres de la mer Blanche. М.; Л.: Изд-во АН СССР, 1938. (Тр. ИААЭ. Т. 9-10. Археол. серия. № 1). Табл. 3. № $49,57,81$.

${ }^{13}$ Колпаков Е.М., Шумкин В.Я. Указ соч. С. 332-336.

${ }^{14}$ Равдоникас В.И. Наскальные изображения
Онежского озера и Белого моря. Ч. 2: Наскальные изображения Белого моря. Les Gravures Rupestres des Bords du lac Onega et de la mer Blanche. Seconde Partie: Les Gravures Rupestres de la mer Blanche. М.; Л.: Изд-во АН СССР, 1938. (Тр. ИААЭ. Т. 9-10. Археол. серия. № 1). Табл. 3.

15 Равдоникас В.И. Наскальные изображения Онежского озера и Белого моря. Ч. 1: Наскальные изображения Онежского озера. Les Gravures Rupestres des Bords du lac Onega et de la mer Blanche. Première Partie: Les Gravures Rupestres du lac Onega. М.; Л.: Изд-во АН СССР, 1936. (Тр. ИААЭ. Т. 9-10. Археол. серия. № 1). С. 79 . № 48.

${ }^{16}$ Линевский А.М. Петроглифы Карелии. Часть 1. Петрозаводск: Каргосиздат, 1939. С. 84.

${ }^{17}$ Poikalainen V., Ernits E. Rock carvings of lake Onega II. The Besov Nos region. Estonian Society of Prehistoric Art. Tartu 2019.610 p.

${ }^{18}$ Колпаков Е.М., Киселева А.М. Указ. соч. С. 110-111.

${ }^{19}$ Колпаков Е.М., Шумкин В.Я. Указ соч. С. 104.

${ }^{20}$ Там же. C. 266. r0n30.

${ }^{21}$ Там же. С. 295.

${ }^{22}$ Там же. С. 317.

23 Чарнолуский B.В. О культе Мяндаша // Скандинавский сборник. Вып. 11. Таллин: Тартуский государственный университет, 1966. С. 301-315.

${ }^{24}$ Колпаков E.M. Кресты и колеса в петроглифах Фенноскандии // Археологические вести. Вып. 20. СПб., 2014. С. 96-104.

${ }^{25}$ Колпаков Е.М., Киселева А.М. Указ. соч. С. 111-112.

\title{
CANOSERO PETROGLYPHS 2020: NEW FIGURES AND TYPOLOGY
}

\author{
(C) 2020 E.M. Kolpakov
}

\section{Institute of Material Culture of the Russian Academy of Sciences, St. Petersburg}

The article presents the most interesting discoveries of rock images from the complex of Canosero petroglyphs on the Kola Peninsula, found in recent years. The author traces their typological connections with the Chalmn-Warre and Zalavruga complexes. Keywords: petroglyphs, North Fennoscandia, Canosero, typology.

DOI: $10.37313 / 2658-4816-2020-2-4-135-142$

\footnotetext{
Evgeny Kolpakov, Doctor of History, Leading Researcher, Paleolithic Department. ORCID 00000002-5648-3406.

E-mail:eugenkolp@yandex.ru
} 